Fountain Journal of Natural and Applied Sciences: 2014; 3(1): 29 - 43
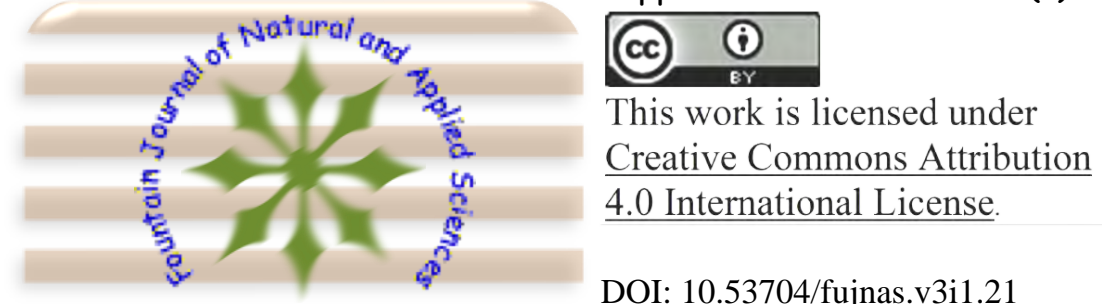

DOI: 10.53704/fujnas.v3i1.21

A publication of College of Natural and Applied Sciences, Fountain University, Osogbo, Nigeria

Journal homepage: www.fountainjournals.com

ISSN: 2354-337X (Online), 2350-1863 (Print)

\title{
Study on the physicochemical properties and heavy metal status of sediment samples from Ohii Miri river in Abia State, Nigeria
}

\author{
Jonah. A. E. ${ }^{1}$. Solomon. M. M. ${ }^{1 \star}$, and Ano. A. O. ${ }^{2}$ \\ ${ }^{1}$ Department of Science Technology, Akwa Ibom State Polytechnic, Ikot Osurua, Akwa Ibom State, Nigeria \\ ${ }^{2}$ Department of Soil Science, National Root Crops Research Institute, Umudike, Abia State, Nigeria
}

\begin{abstract}
The physicochemical properties and heavy metal status of sediment samples from Ohii Miri River in Abia State, Nigeria were studied. The section of the river studied (from Ahia-Eke to Amaoba-Ime) was divided into three segments designated as Stations $A, B$, and $C$. Five sediment samples were collected at each location. Values obtained from the five sampling points were averaged. The sediment samples were analyzed for $\mathrm{pH}$, electrical conductivity, \% organic carbon, \% organic matter, \% ammonium nitrogen, \% nitrate nitrogen, \% nitrogen, \% sand, \% silt, \% clay, and heavy metals ( $\mathrm{Fe}, \mathrm{Pb}, \mathrm{Zn}, \mathrm{Mn}, \mathrm{Ni}, \mathrm{Cd}$, and $\mathrm{Cr}$ ) in the rainy and dry seasons respectively using standard procedures. Correlation analysis was also employed to examine the relationship between the various parameters in the sediment samples. The results obtained for heavy metals were compared with USEPA standard. The results showed that the sediment was acidic and the heavy metals concentrations exceeded the USEPA standard. Positive correlations were found to exist between $\mathrm{Pb}$ with $\mathrm{Zn}, \mathrm{Ni}$; $\mathrm{Fe}$ with $\mathrm{Ni}$ as well as $\mathrm{Ni}$ with $\mathrm{Cd}$ in the rainy season. In the dry season, $\mathrm{Ni}$ correlated positively with $\mathrm{Pb}, \mathrm{Zn} ; \mathrm{Cd}$ with $\mathrm{Pb}, \mathrm{Ni}$. Positive correlations existed between $\mathrm{Cr}$ in dry season with $\mathrm{Cr}$ in rainy season and $\mathrm{Pb}$ in dry season with $\mathrm{Cr}$ in rainy season. PER indices (contamination factor, degree of contamination, ecological risk factor, sum of the individual potential risk, and geo-accumulation factor) have been calculated. Values of geo-accumulation factor showed that the sediment is not polluted with the studied heavy metals.
\end{abstract}

Keywords: Ohii Miri River; Physicochemical parameters; heavy metals; Concentration; Permissible limit; Correlation; Potential ecological risk.

\section{Introduction}

There have been serious concerns, in recent times, on the indiscriminate waste disposal which most often, end up in the water bodies (Omole and Isiorho, 2011; Gani et al., 2013). Before now, water bodies, especially running waters were thought to be the safest means of disposing waste materials. As people become aware of the implication of water pollution on health, several laws prohibiting water pollution have been enacted (Federal Water Pollution Control Act, 2002; Water Pollutant Discharge

*Corresponding author-solomosmon2012@yahoo.com 
Permit System, 2008). However, in developing countries, such law is either not in place or not effective and as such direct waste dumping into water bodies are still in practice. According to Eugene and Busch (2011), 30 to 50\% of wastes generated in the sub Saharan Africa (Nigeria inclusive) are disposed in a way that is detrimental to the environment and public health. Of all the sources of water, surface water is the major recipient of pollutants. Effluents from industries, wastes from agricultural institutions and lands as well as domestic wastes are either directly discharged into surface waters or find their way into it through erosion. Influent seepage of urine and leachate from polluted surroundings such as pit latrine (which are very common in developing countries) or soak-away sited upstream could also enrich surface waters with contaminants (Okoye, 1991). Effluent discharged into water bodies leads to accumulation of contaminants such as heavy metals, organometallic or persistent organic pollutants (Ridgwa and Simmield, 2002). These contaminants become distributed between the aqueous and solid phases of the water bodies. According to Point et al. (2007), the sediment is well recognized as an important sink for the compounds present in the upper water column, through the deposition and the burial of suspended particles. On the other hand, the occurrence of bio-turbation and re-suspension processes, currents and waves, dredging and other anthropogenic activities may enhance the remobilization of these compounds at the sediment-water interface, thus resulting in bioaccumulation and bio magnification processes along the whole tropic chain. These contaminants may adversely affect the physical, chemical, and biological characteristics of water (David and Johanna, 2000). However, many aquatic animals of which man directly or indirectly rely upon for survival live in the sediment and several reports have shown that they are capable of accumulating high concentrations of heavy metals (Tole and Shitsama, 2003; Kumar and Achyuthan, 2007; Soegianto et al., 2008). Several researches have been undertaken to assess the accumulation of contaminants particularly, heavy metals in the water sediment. Addo et al. (2011) studied the water quality and levels of some trace metals in water and sediments of the Kpeshie Lagoon located in Accra, Ghana. The result obtained showed that heavy metals in the sediment especially nickel, lead, and chromium were adjudged a potential health risk to humans and the aquatic life of the lagoon's ecosystem. The contamination status of the heavy metals was confirmed on the basis of enrichment factor and geoaccumulation index. Saeed and Shaker (2008) also reported that $M n$ in Lake Edku sediment and $\mathrm{Cd}$ in Lake Manzala sediment, Egypt were higher than the sediment quality guidelines. Ohii Miri River passes through several communities; Ahiaeke, Ibeku, Umudike and Ama-obaIme, etc in Ikwuano Local Government Area of Abia State. The river passes through so many agricultural establishments; some of them were established more than 20 years ago. These agricultural establishments over the years have been using fertilizers and other agro- chemicals which directly or indirectly end up in Ohii Miri River. Meanwhile, this river is the main source of water for drinking and other household's activities for the communities along its course. Moreover, aquatic animals from this river form a greater percentage of the aquatic animals consumed in Abia State and its environs. This report focuses on the physicochemical properties and the heavy metal status of the sediment samples from Ohii Miri River in Abia State, Nigeria which the findings would be informative for future scientific studies.

\section{Materials and Methods \\ Sampling Area/Collection of Samples}

Ohii Miri River studied originate from Ahia-eke and runs through Federal Department of Agricultural Land Resources, Abia State University, National Root Crops Research Institute, Michael Okpara University of Agriculture and Amaoba - Ime. The portion of the river studied was between Ahia-eke and Amaoba- 
Ime (Figure 1). This portion was divided into three segments referred to in the work as stations $A, B$ and $C$. Station $A$ is the portion of the river from Ahia-eke to Abia State University (ABSU), Umuahia Campus. From ABSU, Umuahia Campus to Michael Okpara University of Agriculture, (MOUAU) is Station B while station C stretches from MOUAU to Amaoba-ime. Each of the stations was divided into five sampling site. Sediment samples collected from station $A$ were labeled S1, S2, S3, S4, S5, station B were labeled 56, S7, 58, 59, S10, and station $C$ were labeled S11, S12, S13, S14, S15. Samples were collected in rainy and dry seasons respectively.

\section{Sample Preparation/Treatment}

The sediment samples were dried and crushed with a wooden roller, sieved with a $2 \mathrm{~mm}$ sieve, labeled and stored in soil bags for chemical and physical parameters determination. The actual method used for the determination of physicochemical properties of the sediment samples was as described by AOAC (2005) and reported elsewhere (Olubunmi and Olorunsola, 2010). Samples for determination of heavy metal was weighed $(2 \mathrm{~g})$ and digested with concentrated $\mathrm{HNO}_{3}$ and $\mathrm{HClO}_{4}$ in the ratio of $4: 1$ as described by Vowotor et al. (2014). The digest was allowed

IKWUANO L.G.A.

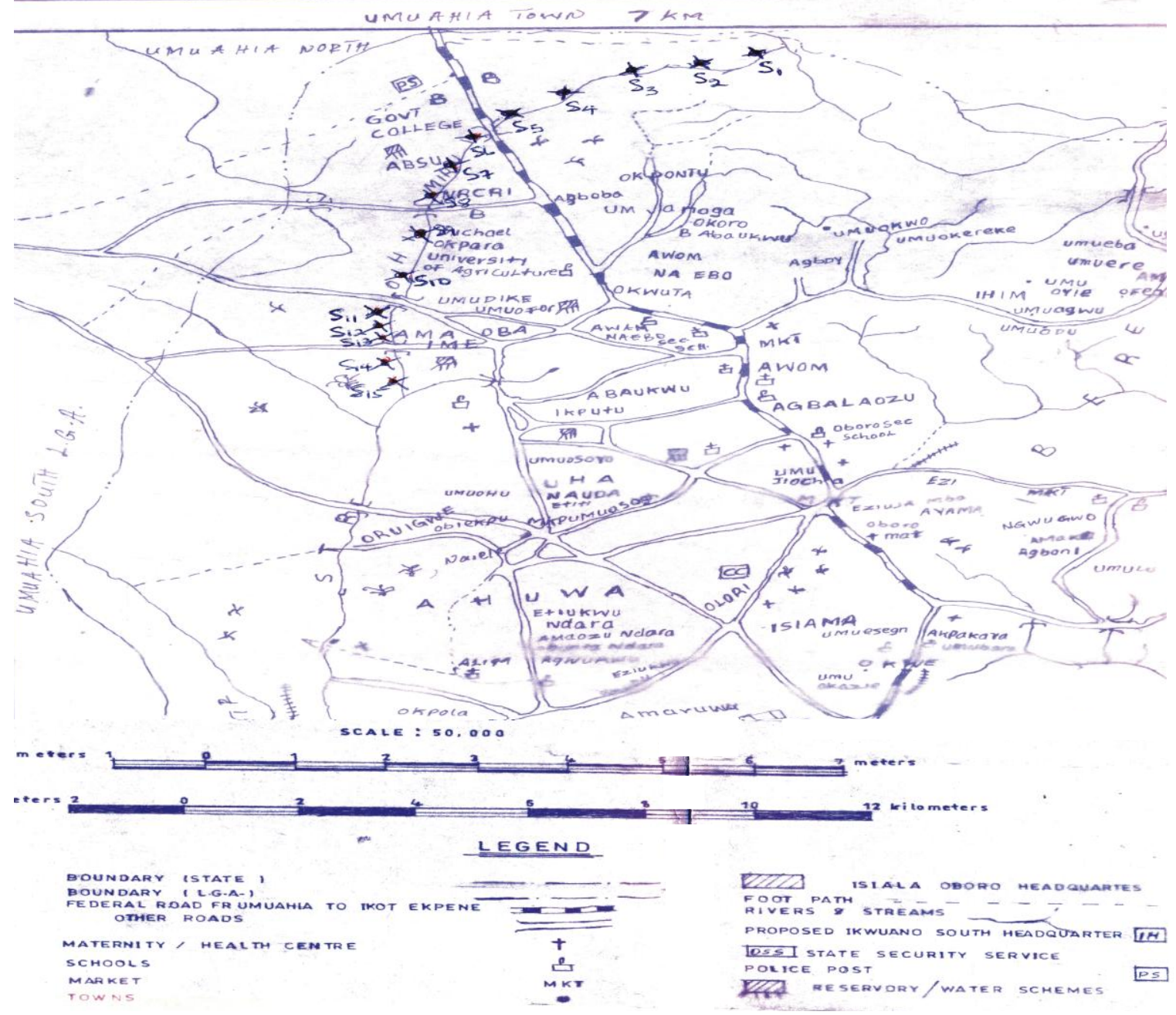

Figure 1: Map of Ikwuano L.G.A. showing the sampling sites 
to cool and transferred into polyethylene bottles, labeled and preserved in the refrigerator prior to metallic elements ( $\mathrm{Fe}, \mathrm{Pb}, \mathrm{Zn}, \mathrm{Mn}, \mathrm{Ni}, \mathrm{Cd}$, and $\mathrm{Cr}$ ) determination using Unicam939/959 atomic absorption spectrophotometer (AAS).

\section{Statistical Analysis}

The data obtained were subjected to analysis of variance. Experimental means were compared using the Duncan new multiple range test (DNMR). Relationships between parameters were examined using correlation analysis (SPSS 17.0 version).

The contamination factor $\left(C_{F}^{i}\right)$ was calculated using equation 1 (Qingjie et al., 2008):

$C_{F}^{i}=\frac{C_{0-1}^{i}}{C_{n}^{i}}$

where $C_{0-1}^{i}$ is the concentration of the examined element in the examined environment, $C_{n}^{i}$ is concentration of the examined element in the reference environment (Table 10). The degree of contamination $\left(C_{d}\right)$, ecological risk factor $\left(E_{r}^{i}\right)$, the sum of the individual potential risk $(R I)$, and the geo-accumulation factor $\left(I_{\text {geo }}\right)$ were calculated using expressions 2, 3, 4, and 5 (Wang et al., 2013) respectively.

$$
\begin{aligned}
& C_{d}=\sum C_{F}^{i} \\
& E_{r}^{i}=T_{r}^{i} \times C_{F}^{i} \\
& R I=\sum E_{r}^{i} \\
& I_{\text {geo }}=\log _{2}\left|C_{0-1}^{i} /\left(1.5 \times C_{n}^{i}\right)\right|
\end{aligned}
$$

where $T_{r}^{i}$ is the metal toxic response factor for a given substance $(\mathrm{Cu}=\mathrm{Pb}=\mathrm{Ni}=5, \mathrm{Zn}=1, \mathrm{Cd}=$ $30, \mathrm{Cr}=2$ ) and the numerical factor '1.5' account for possible variation in background data due to lithogenic effect.

\section{Results and Discussions}

\section{Physicochemical Parameters}

The mean values of physical and chemical properties obtained for the sediment from Ohii Miri River in Abia State, Nigeria in the rainy and dry seasons respectively, are presented in Tables 1 and 2. The gross mean of the parameters [(Station A+ Station B + Station C)/3] is given in Table 3. It is clear from Table 1 that mean values of $4.85 \pm 0.45,5.13 \pm 0.53$ and $4.54 \pm 0.18$ obtained in station $A, B$ and $C$, respectively in rainy season falls within the acid range. A similar trend is observed for $\mathrm{pH}$ in the dry season (Table 2). Close inspection of Table 3 revealed that the water was more acidic in the rainy season $(4.84 \pm 0.46)$ than the dry season $(5.05 \pm 0.30)$. It could be that more acid forming materials such as fertilizer and agrochemicals were being washed into the river by erosion during rainy season. These materials may get settle down in the sediment thus increasing the acidity of the sediment during rainy season (Moore et al., 2009). Meanwhile, this value was not within the maximum permissible limit of $\mathrm{WHO}$ (6.50-7.50) which according to Abulude and Lawal (2002) is an indicator of a good fish population. As could be seen from Table 1, the electrical conductivity of the sediment samples in the rainy season was not significantly different from one another in all the stations. In the dry, season, higher electrical conductivity value of $9.45 \pm 4.16$ $\mu \mathrm{S} / \mathrm{cm}$ was obtained in station $A$ which decreased to $9.21 \pm 2.22 \mu \mathrm{S} / \mathrm{cm}$ in station $B$ and to $6.22 \pm 2.51$ $\mu \mathrm{S} / \mathrm{cm}$ in station $C$. The mean seasonal electrical conductivity in the dry season $(8.29 \pm 3.23 \mu \mathrm{S} / \mathrm{cm})$ was higher than the value of $1.58 \pm 1.26 \mu \mathrm{S} / \mathrm{cm}$ in rainy season (Table 3 ). There is currently no official guideline as to what is considered safe level for conductivity (Karikari, 2007). However, the conductivity of most freshwaters ranged from 10 to $1000 \mu \mathrm{S} / \mathrm{cm}$, but many exceed 1000 $\mu S / \mathrm{cm}$ especially in polluted waters, or those receiving large quantities of land run-off (Chapman, 1992). 
Fountain Journal of Natural and Applied Sciences: 2014; 3(1): 29 - 43

Table 1: Mean concentrations of physicochemical parameter of sediment samples in rainy season for each station

\begin{tabular}{llll}
\hline PARAMETER & STATION A & STATION B & STATION C \\
\hline $\mathrm{pH}$ & $4.85^{\mathrm{b}} \pm 0.45$ & $5.13^{a} \pm 0.53$ & $4.54^{c} \pm 0.18$ \\
Conductivity $\mu \mathrm{s} / \mathrm{cm}$ & $1.52^{\mathrm{a}} \pm 0.94$ & $1.72^{a} \pm 1.96$ & $1.51^{a} \pm 0.90$ \\
\% Organic Carbon & $3.97^{\mathrm{a}} \pm 1.93$ & $7.09^{a} \pm 2.10$ & $7.04^{a} \pm 3.91$ \\
$\%$ Organic Matter & $6.84^{a} \pm 3.33$ & $12.22^{a} \pm 3.62$ & $12.15^{a} \pm 6.73$ \\
$\%$ NH4-N & $0.07^{a} \pm 0.04$ & $0.09^{a} \pm 0.07$ & $0.09^{a} \pm 0.06$ \\
$\%$ NO3 & $0.02^{a} \pm 0.01$ & $0.03^{a} \pm 0.01$ & $0.04^{a} \pm 0.03$ \\
$\%$ N & $0.07^{a} \pm 0.03$ & $0.10^{a} \pm 0.03$ & $0.80^{a} \pm 0.05$ \\
$\%$ Sand & $79.60^{a} \pm 6.07$ & $65.60^{b} \pm 14.24$ & $60.40^{b} \pm 10.35$ \\
$\%$ Silt & $11.80^{a} \pm 4.77$ & $14.20^{a} \pm 6.72$ & $15.60^{a} \pm 8.67$ \\
$\%$ Clay & $8.60^{a} \pm 1.79$ & $20.2^{b} \pm 9.65$ & $24.40^{b} \pm 7.80$
\end{tabular}

Mean values of the same row with the same superscript are not significantly different at $5 \%$ level of probability using DMRT. Station $A=$ Ahia-eke, Station $B=$ Umudike, Station $C=$ Amoeba Ime.

Table 2: Mean concentrations of physicochemical parameter of sediment samples in dry season for each station

\begin{tabular}{llll}
\hline PARAMETER & STATION A & STATION B & STATION C \\
\hline pH & $4.82^{a} \pm 0.21$ & $5.11^{a} \pm 0.21$ & $5.22^{a} \pm 0.34$ \\
Conductivity $\mu \mathrm{s} / \mathrm{cm}$ & $9.45^{a} \pm 4.16$ & $9.21^{a} \pm 2.22$ & $6.22^{a} \pm 2.51$ \\
\% Organic C & $2.10^{a} \pm 0.54$ & $2.46^{a} \pm 1.12$ & $1.55^{a} \pm 0.96$ \\
$\%$ Organic Matter & $3.52^{a} \pm 0.88$ & $4.25^{a} \pm 1.93$ & $2.68^{a} \pm 1.65$ \\
$\% \mathrm{NH}_{4}-\mathrm{N}$ & $0.07^{a} \pm 0.03$ & $0.07^{a} \pm 0.03$ & $0.08^{a} \pm 0.05$ \\
$\%$ NO 3 & $0.03^{a} \pm 0.01$ & $0.03^{a} \pm 0.01$ & $0.04^{a} \pm 0.03$ \\
$\%$ N & $0.18^{a} \pm 0.07$ & $0.23^{a} \pm 0.11$ & $0.13^{a} \pm 0.09$ \\
$\%$ Sand & $67.40^{a} \pm 9.53$ & $64.20^{a} \pm 14.93$ & $64.00^{a} \pm 9.76$ \\
$\%$ Silt & $17.80^{a} \pm 12.60$ & $24.20^{a} \pm 18.09$ & $20.20^{a} \pm 10.73$ \\
\% Clay & $14.80^{a} \pm 7.07$ & $11.60^{a} \pm 5.01$ & $16.40^{a} \pm 10.62$ \\
\hline
\end{tabular}

Mean values of the same row with the same superscript are not significantly different at $5 \%$ level of probability using DMRT. Station $A=$ Ahia-eke, Station $B=$ Umudike, Station $C=$ Amoeba Ime. 
Table 3: Gross mean seasonal concentrations of parameters in sediment samples

\begin{tabular}{lllll}
\hline \multicolumn{1}{r}{ PARAMETERS } & \multicolumn{2}{c}{ RAINY SEASON } & \multicolumn{2}{c}{ DRY SEASON } \\
\hline & MEAN \pm SD & RANGE & MEAN \pm SD & RANGE \\
\cline { 2 - 4 } PH & $4.84^{b} \pm 0.46$ & $(4.25-5.82)$ & $5.05^{a} \pm 0.30$ & $(4.64-5.60)$ \\
$\%$ Organic C & $1.58^{b} \pm 1.26$ & $(0.56-5.22)$ & $8.29^{a} \pm 3.23$ & $(4.06-15.45)$ \\
$\%$ Organic M & $6.03^{b} \pm 3.00$ & $(0.55-10.75)$ & $2.04^{a} \pm 0.93$ & $(0.97-3.68)$ \\
$\%$ NH4-N & $10.40^{a} \pm 5.16$ & $(0.95-18.53)$ & $3.48^{b} \pm 1.58$ & $(1.68-6.34)$ \\
$\%$ NO3-N & $0.08^{a} \pm 0.06$ & $(0.012-0.211)$ & $0.07^{a} \pm 0.04$ & $(0.035-0.155)$ \\
$\%$ Nitrogen & $0.03^{a} \pm 0.02$ & $(0.011-0.078)$ & $0.03^{a} \pm 0.02$ & $(0.020-0.084)$ \\
$\%$ Sand & $0.09^{b} \pm 0.04$ & $(0.035-0.155)$ & $0.18^{a} \pm 0.09$ & $(0.07-0.35)$ \\
$\%$ Silt & $68.53^{a} \pm 13.02$ & $(45.2-85.2)$ & $65.20^{a} \pm 10.93$ & $(41.8-83.8)$ \\
$\%$ Clay & $13.87^{a} \pm 6.60$ & $(5.40-29.40)$ & $20.73^{a} \pm 13.39$ & $(1.40-51.4)$ \\
& $17.6^{a} \pm 9.53$ & $(7.40-33.4)$ & $14.26^{a} \pm 7.61$ & $(6.8-30.8)$
\end{tabular}

Mean values of the same row with the same superscript are not significantly different at $5 \%$ level of probability using DMRT. Station $A=$ Ahia-eke, Station $B=$ Umudike, Station $C=$ Amoeba Ime.

The higher value of conductivity obtained in the dry season is indicative of high concentration of inorganic Dissolved solid (chloride, nitrate, sulphate, phosphates and calcium) in the water since conductivity is related to the concentration of Total Dissolved Solids (TDS) (Addo et al., 2011). It is very clear from Tables 1 and 2 that there were no significant differences ( $p>0.05$ ) between the values of $\%$ organic carbon, $\%$ organic matter, $\%$ ammonium nitrogen, \% nitrate nitrogen and \% nitrogen obtained in each of the stations in the rainy season and dry seasons. However, the gross mean seasonal values (Table 3 ) of \% nitrogen were higher in dry season than the rainy season and differed significantly at $p<0.05$. The mean concentration of organic carbon was also significantly higher in the dry season than the rainy season in the sediment samples. This is indicative of pollution of the water probably by decaying natural organic matter and synthetic sources; detergents, pesticides, fertilizers herbicides and chlorinated organic compounds from the agricultural institutions located along the course of the river (Davis et al., 2006). The percentage sand, silt and clay in the sediment samples in rainy and dry seasons are also given in Tables 1 and 2. In the rainy season, the upper segment of the river (Station A) had significantly the highest mean percentage of sand $(79.6 \pm 6.07 \%)$ and there was no significant difference between the percentages of sand $(65.6 \pm 14.24)$ and $(60.4 \pm 10.35)$ obtained for stations $B$ and $C$. The highest percentage of clay were obtained at the lower segment of the river station $C$ with the value of $24.40 \pm 7.80 \%$ which decreased in the middle segment (Station B) to $20.2 \pm 9.65 \%$ and the upper segment(Station $A$ ) to $8.6 \pm 1.79 \%$. However, there were no significant differences ( $p>0.05$ ) between the value of $\%$ sand, silt and clay obtained in all the stations in the dry season 
Fountain Journal of Natural and Applied Sciences: 2014; 3(1): 29 - 43

Table 4: Mean concentrations of heavy metal concentrations of sediment samples in rainy season for each station

\begin{tabular}{llll}
\hline PARAMETER & STATION A & STATION B & STATION C \\
\hline $\mathrm{Fe}(\mathrm{Mg} / \mathrm{Kg})$ & $21.43^{\mathrm{a}} \pm 2.98$ & $16.35^{\mathrm{b}} \pm 1.90$ & $13.17^{c} \pm 2.40$ \\
$\mathrm{~Pb}(\mathrm{Mg} / \mathrm{Kg})$ & $49.16^{\mathrm{a}} \pm 14.47$ & $44.72^{a} \pm 22.96$ & $25.70^{b} \pm 0.23$ \\
$\mathrm{Zn}(\mathrm{Mg} / \mathrm{Kg})$ & $26.01^{\mathrm{a}} \pm 14.53$ & $37.80^{a} \pm 33.77$ & $9.15^{a} \pm 3.60$ \\
$\mathrm{Mn}(\mathrm{Mg} / \mathrm{Kg})$ & $4.74^{a} \pm 1.17$ & $4.13^{a} \pm 2.15$ & $4.88^{a} \pm 2.31$ \\
$\mathrm{Ni}(\mathrm{Mg} / \mathrm{Kg})$ & $2.01^{a} \pm 0.31$ & $0.85^{b} \pm 0.38$ & $0.43^{b} \pm 0.26$ \\
$\mathrm{Cd}(\mathrm{Mg} / \mathrm{Kg})$ & $0.87^{a} \pm 0.12$ & $0.34^{b} \pm 0.14$ & $0.58^{b} \pm 0.29$ \\
$\mathrm{Cr}(\mathrm{Mg} / \mathrm{Kg})$ & $0.33^{\mathrm{b}} \pm 0.08$ & $0.51^{a} \pm 0.18$ & $0.21^{b} \pm 0.08$
\end{tabular}

Mean values of the same row with the same superscript are not significantly different at $5 \%$ level of probability using DMRT. Station A = Ahia-eke, Station B = Umudike, Station C = Amoeba Ime.

(Table 2). These values obtained for $\%$ sand, silt, and clay are in the range reported by Allessandro (2009). The even distribution of sand, salt, and clay in all the stations ( $A, B$ and $C$ ) particularly in the dry season could be attributed to topography and land forms of the area. The low clay content in some stations suggest that the sediment undergone high degree of weathering and leaching (Mclennan, 1995).

\section{Heavy metals status of Ohii Miri River}

Sediment is very important tracer of metal in aquatic system (Abeh et al., 2007). The concentration of heavy metals in sediment gives an idea of possible pollution status of the water body and also enable protective measures to be taken against excessive exposure either directly or indirectly. According to Davis et al. (2006), sediment is the major depositories of heavy metals holding over $99 \%$ of the total amount of heavy metals in aquatic environment. Tables 4 and 5 present the mean seasonal variation of the heavy metal concentrations of sediment samples from Ohii Miri River in Abia State, Nigeria in the rainy and dry seasons respectively, and the gross average of the seasonal variation of heavy metal concentrations in the sediment [(Station $A+$ Station $B+$ Station $C) / 3$ ] is given in Table 6. From Table 4, it is observed that the concentrations of $\mathrm{Fe}$ in the lower segment (station $C$ ) had the highest significant value of $26.77 \pm 0.45 \mathrm{mg} / \mathrm{kg}$.

The gross mean seasonal concentration of $\mathrm{Fe}$ in the dry season differs significantly ( $p<0.05)$ from the value in the rainy season while there was no significant difference ( $p>0.05)$ between the values of $\mathrm{Pb}$ in the rainy and dry season. Comparing the values of $\mathrm{Fe}$ and $\mathrm{Pb}$ obtained for the two seasons with the permissible limit (USEPA, 1986), it is very clear that the values were far above the permissible values. For instance, $16.98+4.20 \mathrm{mg} / \mathrm{kg}$ (rainy season) and $26.55+.0 .83 \mathrm{mg} / \mathrm{kg}$ (dry season) for $\mathrm{Fe}$ against 1.0 $\mathrm{mg} / \mathrm{L}$ permissible limit and $39.68 \pm 17.93 \mathrm{mg} / \mathrm{kg}$ (rainy season) and $43.40+15.08 \mathrm{mg} / \mathrm{kg}$ (dry season) for $\mathrm{Pb}$ against $0.05 \mathrm{mg} / \mathrm{L}$ permissible limit. This suggests that Ohii River which is the major source of drinking water for people living along the course is heavily polluted with $\mathrm{Fe}$ and $\mathrm{Pb}$. The result obtained for $\mathrm{Fe}$ is in strong agreement with other reports (Asaolu et al., 1997; Asaolu and Olaafe, 2004: Nwajei and Gagophien, 2000; Adefemi and Awokunmi, 2010) that iron occurs at high concentration in Nigeria soil. As warned by 
Table 5: Mean concentrations of heavy metal concentrations of sediment samples in dry season for each station

\begin{tabular}{llll}
\hline PARAMETER & STATION A & STATION B & STATION C \\
\hline $\mathrm{Fe}(\mathrm{Mg} / \mathrm{Kg})$ & $26.47^{\mathrm{b}} \pm 1.04$ & $24.43^{\mathrm{a}} \pm 1.01$ & $26.77^{\mathrm{b}} \pm 0.45$ \\
$\mathrm{~Pb}(\mathrm{Mg} / \mathrm{Kg})$ & $40.05^{\mathrm{a}} \pm 8.00$ & $53.20^{a} \pm 19.85$ & $36.95^{a} \pm 12.35$ \\
$\mathrm{Zn}(\mathrm{Mg} / \mathrm{Kg})$ & $158.28^{\mathrm{b}} \pm 42.61$ & $158.41^{\mathrm{b}} \pm 32.55$ & $115.53^{a} \pm 17.75$ \\
$\mathrm{Mn}(\mathrm{Mg} / \mathrm{Kg})$ & $19.93^{a} \pm 5.56$ & $28.93^{a} \pm 10.50$ & $22.22^{a} \pm 12.52$ \\
$\mathrm{Ni}(\mathrm{Mg} / \mathrm{Kg})$ & $9.24^{a} \pm 1.47$ & $10.93^{a} \pm 4.68$ & $8.77^{a} \pm 1.71$ \\
$\mathrm{Cd}(\mathrm{Mg} / \mathrm{Kg})$ & $2.00^{a} \pm 0.53$ & $2.22^{a} \pm 0.63$ & $2.18^{a} \pm 0.39$ \\
$\mathrm{Cr}(\mathrm{Mg} / \mathrm{Kg})$ & $1.15^{a} \pm 0.21$ & $1.47^{a} \pm 0.34$ & $0.76^{b} \pm 0.25$ \\
\hline
\end{tabular}

Mean values of the same row with the same superscript are not significantly different at $5 \%$ level of probability using DMRT. Station $A=$ Ahia-eke, Station $B=$ Umudike, Station $C=$ Amoeba Ime.

Table 6: Mean seasonal concentrations of parameters in sediment samples

\begin{tabular}{lllll}
\hline \multicolumn{1}{c}{ PARAMETERS } & \multicolumn{2}{c}{ RAINY SEASON } & \multicolumn{1}{c}{ DRY SEASON } \\
\hline & MEAN \pm SD & RANGE & MEAN $\pm S D$ & RANGE \\
\cline { 2 - 5 } $\mathrm{Fe}(\mathrm{mg} / \mathrm{kg})$ & $16.98^{\mathrm{b}} \pm 4.20$ & $(10.53-26.33)$ & $26.55^{a} \pm .0 .83$ & $(24.64-27.29)$ \\
$\mathrm{Pb}(\mathrm{mg} / \mathrm{kg})$ & $39.68^{a} \pm 17.93$ & $(25.38-81.85)$ & $43.40^{a} \pm 15.08$ & $(26-25-87.5)$ \\
$\mathrm{Zn}(\mathrm{mg} / \mathrm{kg})$ & $24.32^{\mathrm{b}} \pm 23.91$ & $(4.03-88.83)$ & $44.08^{a} \pm 36.71$ & $(89.84-198.92)$ \\
$\mathrm{Mn}(\mathrm{mg} / \mathrm{kg})$ & $4.58^{\mathrm{b}} \pm 1.83$ & $(2.61 .-7.93)$ & $23.69^{a} \pm 10.03$ & $(12.16-44.1)$ \\
$\mathrm{Ni}(\mathrm{mg} / \mathrm{kg})$ & $1.10^{\mathrm{b}} \pm 0.75$ & $(0.23 .-2.45)$ & $9.65^{a} \pm 2.94$ & $(6.68-18.65)$ \\
$\mathrm{Cd}(\mathrm{mg} / \mathrm{kg})$ & $0.60^{\mathrm{b}} \pm 0.29$ & $(0.18 .-1.03)$ & $2.13^{a} \pm 0.50$ & $(1.21-2.97)$ \\
$\mathrm{Cr}(\mathrm{mg} / \mathrm{kg})$ & $0.35^{a} \pm 0.17$ & $(0.13 .-0.78)$ & $1.12^{a} \pm 0.39$ & $(0.44-1.87)$
\end{tabular}

Mean values of the same row with the same superscript are not significantly different at $5 \%$ level of probability using DMRT. Station $A=$ Ahia-eke, Station $B=$ Umudike, Station $C=$ Amoeba Ime.

the Centers for Disease Control and Prevention (2003), iron overload can lead to hemochromatosis, a disease characterized by fatigue, weakness, joint pain, abdominal pain, or organ damage. $\mathrm{Pb}$ in the other hand is known for its poisonous nature and USGAO (2000) has reported that $\mathrm{Pb}$ poisoning can cause stunted growth and learning disabilities in children as well as enhance crime and anti-social behavior in children. Also, as documented by WHO (1996), high concentrations of $\mathrm{Pb}$ in the body can cause permanent damage to the central nervous system, the brain, and kidney.
There were no significance differences ( $p>0.05$ ) between the values of $\mathrm{Zn}$ and $M n$ in all the stations in the rainy season (Table 4) but in the dry season, the middle segment of the river (station B) had highest significant values of $158.41 \pm 32.55 \mathrm{mg} / \mathrm{kg}$ and $28.93 \pm 4.68 \mathrm{mg} / \mathrm{kg}$ for $\mathrm{Zn}$ and $M n$ respectively (Table 5 ). However the mean seasonal concentrations of $\mathrm{Zn}$ and $\mathrm{Mn}$ in dry season were higher than the values in the rainy season (Table 6). A comparison of the gross mean seasonal values of $\mathrm{Zn}$ and $\mathrm{Mn}$ (Table 6 ) with the USEPA (1986) standard (1.0 mg/L for $\mathrm{Zn}$ and 0.05 $\mathrm{mg} / \mathrm{L}$ for $\mathrm{Mn}$ ) clearly shows that the 
the concentrations reported that accumulation of manganese in the kidney, liver and bones causes manganese psychosis. High level of $\mathrm{Zn}$ has been associated with disruption in the homeostasis of other essential elements (Anadu et al., 1989). It could be seen also from Table 4 that the upper segment of the river (Station A) had significantly the highest values of $2.01 \pm 0.31 \mathrm{mg} / \mathrm{kg}$ and $0.87 \pm 0.12 \mathrm{mg} / \mathrm{kg}$ for $\mathrm{Ni}$ and $\mathrm{Cd}$ respectively, in the rainy season while significant higher value of $0.51 \pm 0.18 \mathrm{mg} / \mathrm{kg}$ for $\mathrm{Cr}$ was obtained in Station B. There were no significant difference ( $p>0.05)$ between the concentration of $\mathrm{Ni}$ and $\mathrm{Cd}$ in Station $B$ and $C$ respectively in the rainy season. In dry season (Table 5), there were no significant difference between the values of $\mathrm{Ni}$ and $\mathrm{Cd}$ obtained in all the stations. The middle segment of the river (Station B) had significantly the highest $C r$ value of $1.47 \pm 0.38 \mathrm{mg} / \mathrm{kg}$. There was significant difference between the $\mathrm{Cr}$ values of $1.15 \pm 0.21$ and $0.76 \pm 0.25 \mathrm{mg} / \mathrm{kg}$ obtained in Station $A$ and $C$ (Table 5). The mean seasonal concentration of $\mathrm{Ni}$ and $\mathrm{Cd}$ in the dry season was significantly higher than the values in the rainy season (Table 6). Comparing the mean seasonal values (Table 6) of $\mathrm{Ni}, \mathrm{Cd}$, and $\mathrm{Cr}$ with the USEPA
(1986) permissible limits $(\mathrm{Ni}=0.5 \mathrm{mg} / \mathrm{L} ; \mathrm{Cd}=0.01$ $\mathrm{mg} / \mathrm{L} ; \mathrm{Cr}=0.05 \mathrm{mg} / \mathrm{L})$, it is seen that the concentrations of the three metals are only slightly higher than the standard. Generally, the concentrations of $\mathrm{Fe}, \mathrm{Pb}, \mathrm{Zn}, \mathrm{Mn}, \mathrm{Ni}, \mathrm{Cd}$, and $\mathrm{Cr}$ in sediment samples were significantly higher in the dry season than the rainy season. The high concentrations of these heavy metals in the sediment may be due to accumulated effect of continuous release and deposition of wastes containing these metals in the river through erosion, indirect disposal of domestic and agricultural wastes, spilling of loaded crude etc. into the water body. In the dry season, evaporation decreases the volume of the water and hence these metals become more concentrated. These heavy metals, if gain excess into human system through either direct consumption of the water or food chain is capable of posing health problems.

\section{Correlation Analysis}

Correlation analysis was used to examine the relationship between the various parameters in the water samples. Table 7 shows the correlation matrix of the relationship between

Table 7: Correlation matrix for heavy metals concentration in sediment in rainy season

\begin{tabular}{|c|c|c|c|c|c|c|c|}
\hline Heavy metals in sediment in rainy season & & vy metals & n sedime & nt in rain & season & & \\
\hline & $\mathrm{Fe}$ & $\mathrm{Pb}$ & $\mathrm{Zn}$ & $M n$ & $\mathrm{Ni}$ & $C d$ & $\mathrm{Cr}$ \\
\hline $\mathrm{Fe}$ & 1 & & & & & & \\
\hline $\mathrm{Pb}$ & $0.530^{*}$ & 1 & & & & & \\
\hline $\mathrm{Zn}$ & 0.272 & $0.589^{\star}$ & 1 & & & & \\
\hline $\mathrm{Mn}$ & 0.035 & -0.241 & -0.225 & 1 & & & \\
\hline $\mathrm{Ni}$ & $0.868^{\star \star}$ & $0.518^{\star}$ & 0.252 & -0.116 & 1 & & \\
\hline$C d$ & 0.514 & 0.201 & -0.095 & 0.119 & $0.556^{*}$ & 1 & \\
\hline $\mathrm{Cr}$ & 0.090 & 0.199 & 0.461 & -0.106 & -0.021 & -0.319 & 1 \\
\hline
\end{tabular}


heavy metals concentration of sediment in dry season. As could be seen from the table, Ni correlated positively with $\mathrm{Pb}(r=0.565, \mathrm{P}<0.01)$. $\mathrm{Zn}(r=0.565, P<0.05)$ and $C d$ correlated significantly with $\mathrm{Pb}(r=0.623, P<0.05), \mathrm{Zn}(r=$ $0.570, P<0.05)$ and $\mathrm{Ni}(r=0.750, P<0.01)$. This also suggests that they are related and may be from the same source. Table 9 shows the correlation matrix of the relationship between the various concentration of heavy metals in sediment in dry and rainy season. $\mathrm{Fe}$ in rainy season correlated positively and significantly with $\mathrm{Zn}$ in dry season $(r=0.648, P<0.01) . C r$ in dry season correlated positively and significantly with $C r$ in rainy season ( $r=0.912, P<0.01)$ and $\mathrm{Pb}$ in dry season correlated positively and significantly with $C r$ in rainy season $(r=0.617, P<0.05)$.

Table 8: Correlation matrix for heavy metals concentration in sediment in dry season

\begin{tabular}{|c|c|c|c|c|c|c|c|}
\hline \multirow[t]{2}{*}{ Heavy metal in sediment in dry season } & \multicolumn{7}{|c|}{ Heavy metal in sediment in dry season } \\
\hline & $\mathrm{Fe}$ & $\mathrm{Pb}$ & $\mathrm{Zn}$ & $M n$ & $\mathrm{Ni}$ & $C d$ & $\mathrm{Cr}$ \\
\hline $\mathrm{Fe}$ & 1 & & & & & & \\
\hline $\mathrm{Pb}$ & 0.002 & 1 & & & & & \\
\hline $\mathrm{Zn}$ & 0.066 & 0.408 & 1 & & & & \\
\hline$M n$ & -0.157 & -0.019 & 0.188 & 1 & & & \\
\hline $\mathrm{Ni}$ & 0.009 & $0.865^{\star \star}$ & $0.565^{\star}$ & -0.027 & 1 & & \\
\hline$C d$ & 0.287 & $0.623^{\star}$ & $0.570^{*}$ & 0.130 & $0.750^{\star \star}$ & 1 & \\
\hline $\mathrm{Cr}$ & -0.143 & 0.427 & 0.201 & 0.160 & 0.258 & -0.207 & 1 \\
\hline
\end{tabular}

${ }^{*}$ Correlation is significant at the 0.05 level (2-tailed).

${ }^{\star *}$ Correlation is significant at the 0.01 level (2-tailed).

Table 9: Correlation matrix for heavy metals concentration in sediment in rainy and dry seasons

\begin{tabular}{lcccccccc}
\hline Heavy metal levels in dry season & \multicolumn{7}{c}{ Heavy metal levels in rainy season } \\
\hline $\mathrm{Fe}$ & $\mathrm{Fe}$ & $\mathrm{Pb}$ & $\mathrm{Zn}$ & $\mathrm{Mn}$ & $\mathrm{Ni}$ & $\mathrm{Cd}$ & $\mathrm{Cr}$ \\
$\mathrm{Pb}$ & 0.040 & 0.316 & -0.103 & -0.248 & -0.183 & -0.020 & -0.022 \\
$\mathrm{Zn}$ & -0.091 & -0.040 & 0.330 & -0.315 & -0.037 & -0.345 & $0.617^{\star}$ \\
$\mathrm{Mn}$ & $0.648^{\star \star}$ & 0.354 & 0.207 & -0.095 & 0.495 & 0.233 & 0.172 \\
$\mathrm{Ni}$ & 0.162 & 0.220 & 0.514 & 0.161 & -0.041 & -0.103 & 0.250 \\
$\mathrm{Cd}$ & 0.068 & -0.107 & 0.247 & -0.368 & 0.071 & -0.170 & 0.421 \\
$\mathrm{Cr}$ & 0.062 & 0.000 & 0.263 & -0.380 & -0.015 & -0.050 & 0.016 \\
$\mathrm{C}$ & 0.169 & 0.245 & 0.357 & 0.168 & 0.061 & -0.215 & $0.912^{\star \star}$ \\
\hline
\end{tabular}

${ }^{*}$ Correlation is significant at the 0.05 level (2-tailed).

${ }^{\star *}$ Correlation is significant at the 0.01 level (2-tailed). 


\section{Sediment Contamination Assessment}

The Hakanson potential ecological risk (PER) method was employed in assessing the level of pollution of the studied sediment. The PER method was originally developed by Hakanson to assess the characteristics and environmental behavior of heavy metal contaminants in soil sediments (Hakanson, 1980). This assessment which is performed using parallel and equivalent index classification, gives a quantitative approach of predicting the level and extent of potential hazards. The PER technique is based on element abundance and several preconditions (Dumcius et al., 2011; Liu et al., 2009). These preconditions include: concentration (increase in heavy metal concentration increases PER); species number (multiple metals in sediment tend to synergistically increase PER); toxic response (heavy biological toxic metals have high tendency of potential risk); and sensitivity. The contamination factor $\left(C_{F}\right)$ which is usually employed to assess possible anthropogenic input of metals to sediment (Vowotor et al., 2014) was calculated using equation 1 . The results obtained are presented in Table 11. According to the Håkanson (1980) classification, $C_{F}<1$ points to low contamination factor, $1 \leq C_{F}<3$ indicates moderate contamination factor, $3 \leq C_{F}<6$ points to considerable contamination, and $C_{F} \geq 6$ suggests very high contamination factor. It is clear from Table 11 that the $C_{F}$ values are less than unity for all the studied heavy metals in both rainy and dry seasons except for $\mathrm{Pb}$. It can be infer that the sediment from Ohii Miri river is low in $\mathrm{Fe}, \mathrm{Zn}, \mathrm{Mn}, \mathrm{Ni}, \mathrm{Cd}$, and $\mathrm{Cr}$ but moderately enriched with $\mathrm{Pb}$ in both rainy and dry seasons. However, the low values of contamination factor (0.001 to 1.102 in rainy season and 0.001 to 2.152 in dry season) in the sediment show that the slight heavy metal pollution of Ohii Miri river was not likely to originate from anthropogenic activities. The heavy metals probably originated from natural processes. Similar observation has been reported by Olubunmi and Olorunsola (2010) on the heavy metal contamination of Agbabu bitumen deposit area of Ondo State, Nigeria.

The degree of contamination $\left(C_{d}\right)$ which has been used recently by Vowotor et al. (2014) to assess the excessive values of monitored elements in soil sediment samples, was deployed as indicator of the extent of the sediment contamination. This was evaluated using equation 2 and the values obtained for rainy and dry seasons are presented in Table 11. The classification of level of contamination with respect to $C_{d}$ value is that $C_{d}<8$ is indicative of low contamination, $C_{d} \geq 8,<16$ points to moderate contamination, $C_{d}$ $\geq 16,<32$ suggests relatively contamination whereas $C_{d} \geq 32$ indicates very high contamination (Qingjie et al., 2008). It is obvious from Table 11 that the values of $C_{d}$ in both rainy and dry seasons fall under the first class of the $C_{d}$ classification.

Table 10: Consensus-Based Sediment Quality Guidelines of Wisconsin (CBSQG)

\begin{tabular}{lc}
\hline Metal & Consensus Based Sediment Value ( $\mathrm{mg} / \mathbf{k g}$ dry wt) \\
\hline Cadmium & 0.99 \\
Chromium & 43 \\
Iron & 20,000 \\
Lead & 32 \\
Manganese & 460 \\
Mercury & 0.18 \\
Nickel & 23 \\
Zinc & 120 \\
\hline
\end{tabular}

Wisconsin Departmental of Natural Resources (2003) 
The values of the ecological risk factor $\left(E_{r}^{i}\right)$ and the sum of the individual potential risk ( $R I$ ) obtained by using equations 3 and 4 respectively are also presented in Table 11. According to Qinglie et al. (2008), the classification of these indices is as follow: $E_{r}^{i}<40$ is indicative of low contamination: $E_{r}^{i} \geq 40<80$ suggests moderate contamination; $E_{r}^{i} \geq 80<100$ points to strong contamination: $E_{r}^{i} \geq 100<320$ indicates very strong contamination; while $E_{r}^{i} \geq 320$ suggests extremely strong contamination. Similarly, $R I<150$ is indicative of low contamination. $R I \geq 150<300$ points to moderate contamination, $R I \geq 300<600$ suggests strong contamination, while $R I \geq 600$ signifies very strong contamination. Judging from the $E_{r}^{i}$ and $R I$ values shown in Table 11, it can be concluded that the sediments from Ohii Miri river are low in heavy metal contaminants in both rainy and dry seasons. Meanwhile, it is obvious from the table that $C d$ (18.3 in rainy season and 64.58 in dry season) is the most contributing factor to the $R I$ values obtained. This seems to agree with the findings of Ogunkunle and Fatoba (2013) that Nigeria soil is gradually being enriched with $C d$. However, to assess the level of individual heavy metal enrichment in the sediments, chart of $E_{r}^{i}$

Table 11: PER values of heavy metals in Ohii Miri river in the rainy and dry seasons

\begin{tabular}{|c|c|c|c|c|c|c|c|c|c|c|}
\hline \multicolumn{11}{|c|}{ Parameter } \\
\hline \multirow[t]{2}{*}{ Element } & \multicolumn{5}{|c|}{ Rainy season } & \multicolumn{5}{|c|}{ Dry season } \\
\hline & $C_{F}^{i}$ & $C_{d}$ & $E_{r}^{i}$ & $R I$ & $I_{g e o}$ & $C_{F}^{i}$ & $C_{d}$ & $E_{r}^{i}$ & $R I$ & $I_{g e o}$ \\
\hline $\mathrm{Fe}$ & 0.001 & & - & & -5.880 & 0.001 & & - & & -10.143 \\
\hline $\mathrm{Pb}$ & 1.102 & & 5.51 & & -0.445 & 1.203 & & 6.015 & & -0.319 \\
\hline $\mathrm{Zn}$ & 0.203 & -1 & 0.203 & a & -2.888 & 0.367 & -1 & 0.367 & $\dot{Z}$ & -2.030 \\
\hline$M n$ & 0.100 & 今. & - & $\stackrel{g}{\sim}$ & -7.236 & 0.052 & $\underset{\sim}{\sim}$ & - & ọ. & -4.865 \\
\hline $\mathrm{Ni}$ & 0.048 & & 0.240 & $\sim$ & -4.972 & 0.420 & & 2.100 & 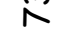 & -1.838 \\
\hline$C d$ & 0.610 & & 18.300 & & -1.308 & 2.152 & & 64.560 & & 0.520 \\
\hline $\mathrm{Cr}$ & 0.008 & & 0.016 & & -7.527 & 0.052 & & 0.052 & & -5.848 \\
\hline
\end{tabular}

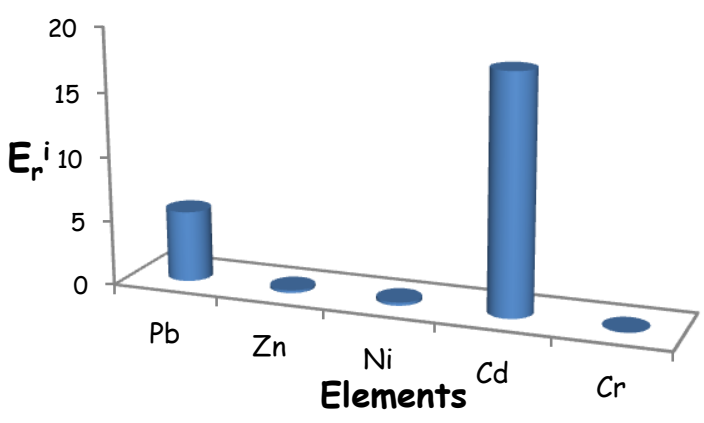

(a)

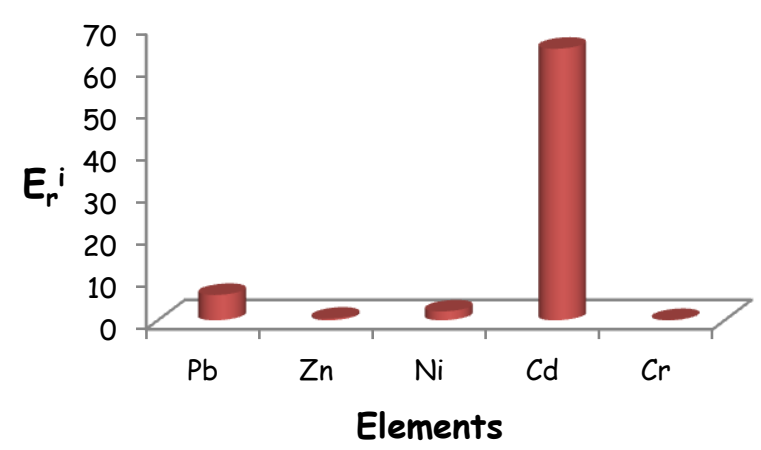

(b)

Figure 2: Ecological risk factor (a) during rainy season (b) during dry season 
versus individual element was plotted for rainy and dry seasons (Figures $2 a$ and $b$ ). The plots show that the level of heavy metal enrichment in the sediment is in the order: $\mathrm{Cd}>\mathrm{Pb}>\mathrm{Ni}>\mathrm{Zn}>\mathrm{Cr}$. A comparison of Figure $2 a$ with $2 b$ reveals that the heavy metal accumulation in the sediment is higher in the dry season than in the rainy season. This might be due to the reduction in the water volume during the dry season due to evaporation. The degree of contamination of the sediment was also evaluated by calculating the geo-accumulation parameter $\left(I_{g e o}\right)$ (equation 5 ) and the results obtained are given in Table 11. Muller (1969) classification of $I_{\text {geo }}$ grouped it into seven grades: $I_{\text {geo }} \leq 0$ (grade 0), unpolluted; $0<I_{\text {geo }} \leq 1$ (grade 1), slightly polluted; $1<I_{\text {geo }} \leq 2$ (grade 2), moderately polluted; $2<I_{\text {geo }} \leq 3$ (grade 3), moderately severely polluted; $3<I_{\text {geo }} \leq 4$ (grade 4), severely polluted; $4<I_{\text {geo }} \leq 5$ (grade 5), severely extremely polluted; and $I_{\text {geo }}>5$ (grade $6)$, extremely polluted. It can be clearly seen from Table 11 that the $I_{g e o}$ values of all the studied metals were lower than unity and negative in both seasons except $\mathrm{Cd}$ in the dry season. It can be concluded based the Muller's grading that the metals were grade 0 and the sediments were not polluted in both seasons. However, Olubunmi and Olorunsola (2010) have noted that the $I_{\text {geo }}$ factor is not readily comparable with enrichment factor due to the nature of $I_{g e o}$ calculation which involves a logarithm function and a background multiplication factor of 1.5 .

\section{Conclusion}

This study has established that Ohii Miri River is acidic and hard hence might not be very good for direct consumption. The sediment is highly enriched with inorganic dissolved solid such as chloride, nitrate, sulphate, phosphates and calcium. Positive correlations exist between $\mathrm{Pb}$ with $\mathrm{Zn}$ and $\mathrm{Ni}, \mathrm{Fe}$ with $\mathrm{Ni}$, and $\mathrm{Ni}$ with $\mathrm{Cd}$ in the rainy season; $\mathrm{Ni}$ with $\mathrm{Pb}, \mathrm{Zn}$ and $\mathrm{Cd}$ with $\mathrm{Pb}$ and $\mathrm{Ni}$ in the dry season. Also, Positive correlations exist between $\mathrm{Cr}$ in dry season with $\mathrm{Cr}$ in rainy season and $\mathrm{Pb}$ in dry season with $\mathrm{Cr}$ in rainy season. More so, PER indices revealed that the river is not highly contaminated with heavy metals.

\section{Acknowledgements}

The researchers are grateful to the Akwa Ibom State Polytechnic, Ikot Osurua, Akwa Ibom State, Nigeria and the National Root Crops Research Institute, Umudike, Abia State, Nigeria for their financial assistance

\section{References}

Abeh, T., Gunshik, J., and Adamu, M. M. (2007). Separation studies of trace elements level in sediment from Zarmaganda stream in Jos, Plateau state, Nigeria. J. Chem. Soc. Nigeria 32 (2):218 -24.

Abulude, F.O. and Lawal, L. (2002). Analysis of selected nutrients of wine obtained from felled palm tree. Pak. J. Sci. Int. Res. 45: 386-387.

Addo, M.A., Okley, G.M., Affum, H.A., Acquah, S., Gbadago, J.K. (2011). Water quality and level of some heavy metals in water and sediments of Kpeshie Lagoon, La-Accra, Ghana. Res. J. Environ. Earth Sci. 3 (5): $487-497$.

Adefemi, S.O., Awokunmi, E. E. (2010). Determination of physico-chemical parameters and heavy metals in water samples from Itaogbolu area of Ondo State, Nigeria. African J. Environ. Sci. Technol. 4(3): 145 - 148.

Allessandro, A., Sergio, P., Giorgio, M., Pietro, R. (2009). Heavy metal contents and Distribution in Coastal Sediments of the Gulf of Trieste(Northern Adriatic Sea, Italy).Water Air Soil Pollut. 211:95-111.

Aossociation of Official Analytical Chemist, AOAC, (2005). Official Method of Analysis Association of Analytical Chemist. Washington, DC, 15th ed.,pp: 11 14. 
Anadu, D.J., Chapman, G.A., Guitis, L.R., Tubb, R.A.(1989). Effect of zinc exposure on subsequent acute tolerance to heavy metals in rainbow trout. Bull. Environ. Contam. Texicol. 43: $329-336$.

Asaolu, S.S.(1998). Chemical pollution studies of coastal water of Ondo State. Ph.D Thesis, Fed. Univ. Technol., Akure, Unpublished.

Asaolu, S.S., Olaofe, O. (2004). Biomagnification factors of some heavy and essential metals in sediments, fish and crayfish from Ondo State Coastal region. Bio. Sci. Res. Commu. 16: 33 - 39.

Centers for Disease Control and Prevention (2003). Hemochromatosis: an iron overload disease. Information for patients and their families. Link: www.cdc.gov/ncbddd/hemochromatosis/p f/ironoverload_508.

Chapman, D. (1992). Water Quality Assessment: A Guide of the use of Biota, Sediments and Water in Environmental Monitoring. University Press, Cambridge, p: 585.

Dara, S.S. (1993). A text book of Environmental Chemistry and pollution control. S. Chand and company, Ram Nagar, New Delhi, pp.167- 207.

David, H. and Johanna, E. J. (2000). Organochlorine, heavy metal and polyaromatic hydrocarbon pollutant concentrations in the great barrier reef (Ausralia) environment - A review. Marine Pollution Bulletin 41: $267-278$.

Davis, J.G., Bander, F.A., Maston, R.M. (2006). Irrigation water quality criteria; No 0506, Colorado State University Extension Agriculture.

Dumcius, A., Paliulus, D., Kozlovska-Kedziora, J. (2011). Selection of investigation methods for heavy metal pollution on soil and sediments of water basins and river bottoms- A review. Ekologija 52 (1): 3038.

Eugene, A. and Busch, G. (2011). Community based solid waste management in Sub-Saharan Africa. The case of Buea-Cameroon-11480.
WM2011 Conference, February 22 March 3, 2011 Phoenix, AZ.

Federal Water Pollution Control Act(2002). An Act to provide for water pollution control activities in the public health service of the Federal Security Agency and in the Federal Works Agency, and for other purpose. As amended through P. L. 107 303.

Gani, B.A., Abubakar, M.Y., Babanyara, Y.У. (2013). Indiscriminate solid waste disposal in Bauchi: causes and impacts on the community and the environment. $\mathrm{J}$. Environ. Earth Sci. 3 (4): 2224 - 3216.

Håkanson, L. (1980). An ecological risk index for aquatic pollution control-a sedimentological approach. Water Res. 14: 975-1001.

Karikari, A.Y., Asante, K. A. and Biney, C. A. (2007). Water quality characteristics at the estuary of Korle Lagoon in Ghana. Unpublished paper. CSIR-Water Research Institute, P.O. Box M32, Accra-Ghana.

Kumar, K.A., Achyuthan, H. (2007). Heavy metal accumulation in certain marine animals along the coast of Chennai, Tanil Nadu, India. J. Environ. Biology 28 (3): 637 648.

Liu, J., Li, Y., Zhang, B., Cao, J., Cao, Z., and Domagalski, J. (2009). Ecological risk of heavy metals in sediments of the Luan River source water. Ecotoxicology 18: 748 $-758$.

McLennan, S. M. (1995). Sediments and soils: Chemistry and Abundance, American Geophysical Union, New York, pp. 17942100.

Muller, G. (1969). Index of geoaccumulation in sediments of the Rhine River. Geology Journal 2: 109-118.

Moore, F., Forghani, G., and Qishlaqi, A. (2009). Assessment of heavy metal contamination in water and surface sediments of the Malarlu saline lake, SW Iran. Iranian J. Sci. Technol. Transaction A 33 (A1): 4455. 
Nwajei, G.E., Gagophien, P.O. (2000). Distribution of heavy metals in the sediments of Lagos Lagoon. Pak. J. Sci. Ind. Res. 43:338 - 340.

Ogunkunle, C. O. and Fatoba, P. O. (2013). Pollution loads and the ecological risk assessment of soil heavy metals around a mega cement factory in Southwest Nigeria. Pol. J. Environ. Stud. 22 (2): 487 - 493.

Olubunmi, F. E. and Olorunsola, O. E. (2010). Evaluation of the status of heavy metal pollution of sediment of Agbabu bitumen deposit area, Nigeria. Euro. J. Sci. Res. 41 (3): $373-380$.

Okoye, C.O.B. (1991). Heavy metals and organisms in the Lagos, Lagoon. Internal. J. Environ. Studies 37: $285-292$.

Omole, D.O. and Isiorho, S.A. (2011). Waste management and water quality issues in Coastal States of Nigeria: The Ogun State experience. Journal of Sustainable Development in Africa 13(6):207-217.

Piont, D., Monperrus, M., Tessier, E., Amouroux, D. (2007). Biological control of trace metal and organometal benthic fluxes in a entrophic lagoon. Estuarine Coastal and Shelf Sciences 72(3): 457-471.

Qingjie, G., Jun, D., Yunchuan, X., Qingfei, W., Ligiang, Y. (2008). Calculating pollution indices by heavy metals in ecological geochemistry assessment and a case study in Park of Beijing. J. China University of Geosciences 19 (3): $230-241$.

Ridgway, J., Shimmield, G. (2002). Estuaries as repositories of historical contamination and their impact on shelf areas. Estuarine Coastal and Shelf Sciences 55: 903-928

Saeed, S.M., Shaker, I.M. (2008). Assessment of heavy metals pollution in water and sediments and their effect on Oreochromis niloticus in the northern delta lakes, Egypt. $8^{\text {th }}$ International Symposium on Tilapia in Aquaculture, 475 - 489.

Soegianto, A., Irawan, B., Hamami (2008). Bioaccumulation of heavy metals in aquatic animals collected from coastal waters of Gresik, Indonesia. Asian J. Water Environ. Pollution 6 (2): 95 - 100.

Tole, M.P., Shitsama, J.M. (2003). Concentrations of heavy metals in water, fish, and sediments of the Winam Gulf, Lake Victoria, Kenya. Aquatic Ecosystem Health and Manage Soc $1: 1-9$.

United States General Accounting Office, USGAO (2000). Health effect of lead in drinking water. U.S. General Accounting Office reports.

United States Environmental Protection Agency, USEPA (1986). Quality Criteria for Water. Office of Water Regulation and Standards, Washington DC, USEPA 40015-86-001, 256.

United States Environmental Protection Agency, USEPA, (2004). Drinking water health advisory for manganese. Health and Ecological Criteria Division, Washington DC, 20460. Http://www.epa.gov/safewater Vowotor, M. K., Hood, C. O., Sackey, S. S., Owusu, A., Tatchie, E., Nyarko, S., Osei, D. M., Mireku, K. K., Letsa, C. B., and Atieomo, S. M. (2014). An assessment of heavy metal pollution in sediment of a tropical lagoon. $A$ case study of the Benya Lagoon, Komenda Edina Eguafo Abrem Municipality (KEEA) Ghana. J. Health \& Pollution 4 (6): $26-39$.

Wang, J., Liu, W., Yang, R., Zhang, L., and Ma, J. (2013). Assessment of the potential ecological risk of heavy metals in reclaimed soils at an opencast coal mine. Disaster Advances 6 (S3): 366 - 377.

Water Pollutant Discharge Permit System, WPDPS, (2008). Art 59.

World Health Organization ,WHO, (1998). Guidelines for Drinking Water, WHO Criteria and Other Supporting Information, WHO, Geneva. 